\title{
Chest Wall Mass
}

National Cancer Institute

\section{Source}

National Cancer Institute. Chest Wall Mass. NCI Thesaurus. Code C39661.

An abnormal growth in the chest wall. 